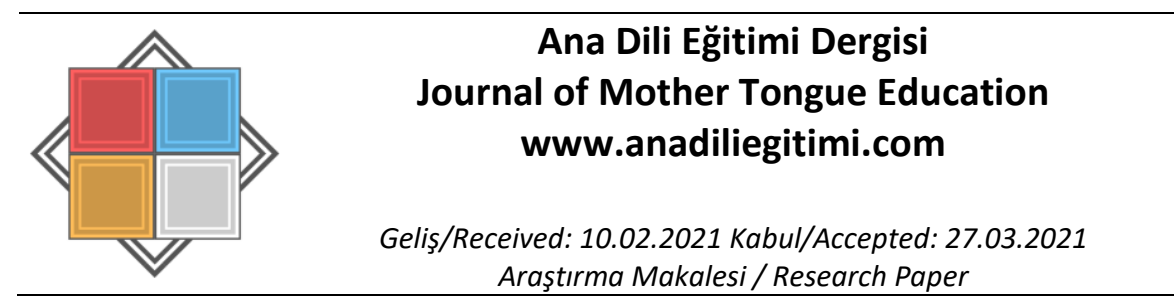

\title{
2019 Türkçe Dersi Öğretim Programı 6. Sınıf Kazanımlarının Değerlendirilmesi
}

\author{
Serdar ARCAGÖK*
}

\begin{abstract}
Öz
Bu araştırmanın amacı 2019 Türkçe Dersi Öğretim Programı 6. sınıf kazanımlarını belirli ölçütlere göre değerlendirmektir. Araştırmada genel tarama modellerinden kesitsel tikel tarama modeli kullanılmıştır. Araştırmanın çalışma grubunu 2020-2021 öğretim yılında Türkiye'nin 12 farklı bölgesinde çeşitli üniversitelerdeki Türkçe eğitimi ana bilim dalında görev yapmakta olan 35 öğretim üyesi oluşturmaktadır. Araştırmadaki veri toplama aracını "6. Sınıf Türkçe Dersi Öğretim Programı Kazanımlarını Değerlendirme Formu" oluşturmaktadır. Elde edilen veriler çok yüzeyli Rasch'a dayalı analizlerle gerçekleştirilmiştir. Araştırma sonuçlarına göre programın kazanımlarını değerlendirmede kullanılan ölçütlerin katılık ve cömertlik bakımından farklılaştığı saptanmıştır. Ayrıca öğretim üyelerinin programdaki ölçütlerin büyük bölümüne katıldıkları, bazı ölçütlere ise katılmadıkları nicel veriler doğrultusunda saptanmıştır. Araştırmada öğretim üyelerinin programın uzak hedeflerine ve eklektik yapısına yönelik eksiklikler olduğuna yönelik görüş belirttikleri ortaya çıkmıştır. Bu bağlamda 2019 Türkçe Dersi Öğretim Programı 6. sınıf kazanımlarının farklı paydaşların görüşleri alınarak tekrar incelenmesi düşünülebilir
\end{abstract}

Anahtar Kelimeler: Çok yüzeyli Rasch analizi, öğretim programı, puanlayıcı yanlılığı, Türkçe dersi

\begin{abstract}
An Evaluation of the 2019 Turkish Course Curricula $6^{\text {th }}$ Grade Learning Outcomes Abstract

The aim of this research is to evaluate the 2019 Turkish course curricula $6^{\text {th }}$ grade learning outcomes in terms of a variety of variables. The study used a cross-sectional single survey model. The study group consisted of 35 faculty members working in the Turkish education departments of various universities located in 12 different locations in Turkey during the 2020-2021 academic year. The data collection tool is the " $6^{\text {th }}$ Grade Turkish Course Curriculum Outcomes Evaluation Form". The results showed that the faculty members agreed upon most of the criteria in the program, but did not agree upon some. The faculty members stated that there were deficiencies in the curriculum regarding the remote goals and the eclectic structure of the program. Thus, a reexamination of the $6^{\text {th }}$ grade Turkish course curriculum learning outcomes by obtaining the opinions of different stakeholders may be essential.
\end{abstract}

Keywords: Multi-faceted Rasch analysis, curricula, rater bias, Turkish course

\section{Giriş}

Bireylerin bilgiyi kazanma süreçleri ilk olarak ailede başlamaktadır. Bireyler genel olarak okul dönemleri başlayana kadar bilgileri sorgulamadan kabul etmektedirler. Bilginin, aşamalı ve düzenli bir şekilde bireye aktarılması ise eğitim-öğretim süreciyle beraber gerçekleşmektedir (Büyükarslan, 2011). Bu süreçte öğretim programları yoluyla bilgiler düzenli olarak öğretmenler aracılığıyla öğrencilere aktarılabilmektedir. Okullardaki bilgi aktarımı ise temelde dil aracılığı ile olmaktadır. Dil ne kadar düzgün ifadeler ile kullanılırsa iletilecek mesaj da o kadar açık ve anlaşılır olacaktır. Korucu (2016)'ya göre dil bilincine sahip bireylerin bir araya gelmesi ve o dilin geçmişte atılan temelleri güçlü bir dilin

\footnotetext{
* Dr. Öğr. Üyesi, Çanakkale Onsekiz Mart Üniversitesi, Eğitim Fakültesi, Temel Eğitim Bölümü, Çanakkale, serdar_arcagok21@comu.edu.tr, ORCID: orcid.org/0000-0002-4937-3268.
} 
inşa edilmesini sağlamaktadır. Dilin bilinçli kullanılabilme becerisinin kazandırılabileceği en iyi ortam ise ilkokullardaki Türkçe dersleri olarak görülmektedir.

Bireyin zihinsel gelişimi ve toplumun ihtiyaçlarına yönelik olarak gereken dil becerilerini kazanabilmesinde anadili temel alan Türkçe öğretimi etkili olmaktadır. Anadilin doğru öğretilerek düzgün konuşulması hedeflenmektedir. Bunun en temel yolu ise, ilköğretimdeki Türkçe programlarının başarılı uygulanmasıyla mümkün olmaktadır (Sandıkçı, 2006).

Öğrenciler öğretmen gözetiminde kurallı ana dil eğitimi alarak sözcük dağarcıklarını zenginleştirmekte, anlama ve anlatma becerilerini de geliştirmektedirler (Akar, 2019). Anlama dinleme ve okuma becerisi ile anlatma ise konuşma ve yazma becerileriyle gelişmektedir (Mutlu ve Yurt, 2019). Türkçe derslerinde, öğrencilerin kendilerini daha iyi ifade etmeleri ve düşüncelerini aktarmaları için sistematik olarak ana dili öğretilmektedir. Böylece bireyler kendilerini doğru ve açık ifade edebilen ve karşısındaki bireylerin duygularını, düşüncelerini, algılarını, yaşam biçimlerini ve kültürlerini de anlayabilen kişiler olarak yetişmektedirler (Mert-Duran, 2016). Bununla beraber öğrencilerin iletişim becerileri geliştirilerek onları hayata hazırlamak amaçlanmaktadır. Öğrencilerin yaşadıkları toplumda kendilerini ifade edebilmeleri ve bu ortamda olup biteni algılamaları iletişim sayesinde mümkün olmaktadır. Bu temel becerilerin kazandırılması için gerekli olan Türkçe öğretim süreci ise öğretim programıyla doğrudan bağlantılıdır (Avcı, 2018; Mutlu ve Yurt, 2019). Nitekim öğretim programı okul içinde veya okul dışında etkinlikler aracılığıyla öğrencilere kazandıııması gereken bilgi, beceri ve tutumları kapsayan bir yapıdır (Er, 2011). Öğrencilere kazandırılması istenen bilgi, beceri ve tutumlar çağın koşullarına göre şekillenmektedir. Bu bağlamda öğretim programları da toplumu geleceğe hazırlamada başat rol oynayan eğitim kurumları tarafından bu gereksinimler doğrultusunda yeniden düzenlenmiştir (Kayhan, Altın ve Gürol, 2019). Bu düzenlemelerden ülkemizdeki Türkçe öğretim programları da etkilenmiştir.

Türkçe öğretim programı Millî Eğitim Bakanlığı tarafından eğitim programının amaçları doğrultusunda hazırlanan, temel dil becerilerinin planlı bir biçimde bireylere kazandırılması hedeflenen program (Kırkpınar - Nural, 2019) olarak tanımlanmaktadır. Bu program aracılığıyla öğrencilerin öğrenmeleri gereken bilgi, beceri ve tutumlar belirlenerek etkinlikler aracılığıyla onlara ulaşılması hedeflenmektedir. Programda, okuma, dinleme/izleme, konuşma, yazma temel dil becerileriyle dil bilgisi alanı bir bütün olarak ele alınmaktadır. Ayrıca öğrenme sürecinin de etkinliklerle zenginleştirilmesi gerektiği vurgulanmaktadır (Doğu, 2010). Tüm bunların gerçekleşebilmesi için programın hedefleri olan kazanımların niteliklerine dikkat edilmesi gerekmektedir. Okullarda öğrencilerin kazanacakları beceriler, onların eğitim hayatlarını ve okul dışındaki yaşamlarını başarılı, güvenli, mutlu ve sorunsuz olarak yürütebilmelerini sağlayacaktır (Karadağ, 2012). Öğretim programlarının toplumun kültürü, yapısı, beklentileri ve gereksinimleri ile bireylerin bilgi, tutum ve becerilerini dengeleyecek bir yapıda olması gerekmektedir.

Türkçe öğretim programlarının Cumhuriyetten bu yana ülkemizde farklı tarihlerde değişikliğe uğradığı dikkat çekmektedir. 1924, 1926 ve 1930 'lu yıllarda ilk mektep Türkçe programları şeklinde tanımlanmış, 1936,1948 ve 1968 yıllarında ilkokul Türkçe programları olarak ifade edilmiştir. 1981, 1998, 2005, 2009, 2015 yıllarında ise ders temelli olarak Türkçe öğretim programlarının düzenlendiği görülmektedir (Şahin ve Bayramoğlu, 2016). Bu yaklaşımın 2018 yılında hazırlanan Türkçe öğretim programında da sürdüğü anlaşılmaktadır.

Türkçe dersi kazanımlarının ve belirlenen hedeflerinin gerçekleştirilebilmesi için nitelikli öğretim programları oluşturulmalıdır (Dilidüzgün, 2009). Türkçe Dersi Öğretim Programı́nda öğrencilerin bireysel farklııkları dikkate alınarak programın öğretmenler tarafından öğrencilere uyumlu hale getirilmesi hedeflenmektedir. Bununla beraber öğretmenlerden yapılandırmacı yaklaşım ve öğrenme psikolojisi alanlarında yetkinliklere sahip olarak öğrenci merkezli eğitim vermeleri beklenmektedir (Epçaçan ve Erzen, 2008). Böylece öğrenciler becerileri ve becerilerle ilgili kazanımları; karşılaştıkları nesneler, olaylar ve materyaller hakkındaki bilgileri işlemekle kullanmaktadırlar.

Millî Eğitim Bakanlığı'nca yürütülen program geliştirme çalışmaları doğrultusunda ilköğretim ikinci kademe (6-8. sınıflar) için yeni program hazırlanarak pilot uygulaması 2005-2006 öğretim yılında yapılmıştır. Program 2006-2007 öğretim yılında ise Türkiye'deki tüm ilköğretim okullarının 6 . sınıflarında uygulanan programın yapılandırmacı yaklaşım temel alınarak öğrenciyi merkeze alan ve 
işbirlikçi öğrenmenin, bireysel farklılıkların dikkate alındığı öğretimin ve çoklu zekanın önemsendiği bir program (Doğu, 2010; Karakoç-Öztürk, 2008) olduğu görülmektedir. Bu çerçevede programın yapılandırmacı yaklaşımdaki bireylerin etkin zihinsel süreçlerle yaparak yaşayarak öğrenmeyi deneyimledikleri, bilgiyi yeniden yapılandırdıkları bir süreci (Spigner Littles ve Anderson, 1999) içerdiği söylenebilir.

Ülkemizde ilköğretimdeki zorunlu eğitim süresinin 4+4+4 şeklinde 12 yıla çıkarılması, çağın ihtiyaçlarının dikkate alınması, bilgi çağının zorunlulukları (Atik ve Aykaç, 2017) Türkçe Dersi Öğretim Programının da yeniden değerlendirilmesine yol açmıştır. Bu çerçevede 2012-2013 öğretim yılından itibaren 2009 yılında hazırlanan Türkçe Dersi Öğretim Programı da yine yapılandırmacı yaklaşım merkeze alınarak hazırlanmış bununla beraber beyin temelli öğrenme, çoklu zekâ, öğrenci merkezli eğitim, bireysel farklılıklara duyarlıık, sarmal yaklaşım, tematik ve beceri yaklaşımı gibi farklı eğitim yaklaşımları da kullanılmıştır (Avcı, 2018).

2015 yılında hazırlanan Türkçe Dersi (1-8.Sınıflar) Öğretim Programı incelendiğinde programın öğrencilerin yaşamlarının tümünde kullanacakları iletişim, okuma ve yazma ile ilgili dil ve zihinsel becerileri kazanabilmelerini hedeflediği ortaya çıkmaktadır. Bu programda öğrencilerin bireysel ve sosyal olarak kendilerini geliştirmeleri, etkili iletişim kurmaları, Türkçe sevgisi geliştirmeleri, istekli okuma ve yazma alışkanlığı kazanmalarını sağlayacak bilgi, beceri ve değerlerle donanmaları beklenmektedir (MEB, 2015).

2018 yılında hazırlanan Türkçe Dersi Öğretim Programı ise öğrencilerin dinleme/izleme, konuşma, okuma ve yazma ile ilgili dil becerileri ve zihinsel becerilerini kazanmaları beklenmektedir. Kazanılan bu becerilerin kullanılarak öğrencilerin bireysel ve sosyal yönden gelişmelerini, etkili iletişim kurabilmelerini, Türkçe dilini severek istekli okuma ve yazma alışkanlığı edinmelerini sağlayan bilgi, beceri ve değerleri içererek bütünleştirilmesi amaçlanmaktadır (MEB, 2019).

İlgili alan yazın incelendiğinde 6. sınıf Türkçe öğretim programının farklı boyutlarının araştırmacılar tarafından irdelendiği görülmektedir. Bu araştırmaların bir bölümünün programın öğrenme alanlarını (Mutlu ve Yurt, 2019) ve çeşitli temalarını (Korucu, 2016; Kurt, 2018) incelediği saptanmıştır. Bununla birlikte araştırmaların eğitsel oyunların programda bulunan etkinlerini inceleyen araştırmaya da rastlanmıştır (Şahin, 2019). 6. sınıf Türkçe öğretim programındaki farklı becerileri inceleyen araştırmalar da bulunmaktadır (Direkçi, Şimşek ve Uygun, 2020; Kurudayıoğlu ve Soysal, 2019; Özenç, 2018). Ayrıca 6. sınıf Türkçe öğretim programını karşılaştırmalı olarak değerlendiren araştırmalar da tespit edilmiştir (Altunkeser ve Coşkun, 2016; Aslan ve Atik, 2018; Özenç, 2018). 6. sınıf Türkçe öğretim programını değerlendiren araştırmaların genellikle yedinci ve sekizinci sınıf Türkçe öğretim programı ile değerlendirildiği araştırmalarla birlikte ele alındığı ortaya çıkmaktadır (BeletBoyacı ve Güner-Özer, 2019; Kahtalı ve Çelik, 2020; Kardaş, 2020, Süğümlü, Mutlu ve Cinpolat, 2019). Bu bağlamda 6. sınıf Türkçe öğretim programını detaylı irdeleyen araştırma sayısının sınırlı olması dikkat çekmektedir. Öğretim programlarının detaylı olarak incelenmesi ve değerlendirilmesi, programların niteliği, yaygın etkisi, paydaşlara katkısı ile işlevselliği hakkında bilgi verecektir. Bunun yanı sıra zaman ve mekânın yakınsadığı, toplumun ve bireyin gereksinimlerinin hızlı şekilde değiştiği günümüzde programların güncel araştırmalarla incelenmesinin büyük önem taşıdığı düşünülmektedir. Nitekim öğretim programının değerlendirilmesi öğrenme hedeflerinin, çıktılarının, araç gereçlerinin ve deneyimlerinin programa ilişkin karar vermedeki betimlemelerini kapsamaktadır (Klenowski, 2010). Nitekim öğrenme sürecinin etkililiği öğretim programlarının bilimsel süreçler dikkate alınarak belirli zaman dilimlerinde incelenmesi ve değerlendirilmesi ile mümkündür (Girgin, 2011). Bu çerçevede araştırmanın 6. sınıf Türkçe öğretim programının değerlendirilmesinin alana katkıda bulunacağı beklenmektedir.

Bu noktadan hareketle araştırmanın amacı 2019 Türkçe Dersi Öğretim Programı 6. sınıf kazanımlarını çok yüzeyli rasch analizi ile değerlendirmektir. Bu amaca bağlı olarak aşağıdaki araştırma soruları incelenmiştir.

1. 2019 Türkçe Dersi Öğretim Programı 6. sınıf kazanım ölçütlerinin kapsam geçerlik oranları ve kapsam geçerlik indeksleri ne düzeydedir?

2. 2019 Türkçe Dersi Öğretim Programı 6. sınıf kazanımlarının çok yüzeyli rasch modeli ile incelenmesi sonucundaki logit değerleri ve veri kalibrasyon haritasında dağılım nasıldır? 
3. 2019 Türkçe Dersi Öğretim Programı 6. sınıf kazanımlarını puanlayan puanlayıcıların katılık/cömertliklerine ait istatistiksel bilgileri hangi düzeydedir?

4. 2019 Türkçe Dersi Öğretim Programı 6. sınıf kazanımlarının değerlendirildiği ölçütlere ilişkin ölçüm raporu nasıldır?

\section{Araştırmanın Modeli}

\section{Yöntem}

Araştırmada genel tarama modellerinden kesitsel tikel tarama modeli kullanılmıştır. Kesitsel tikel tarama modelinde var olan duruma müdahale edilmeden, araştırma verileri yalnızca bir ölçümle elde edilmektedir (Fraenkel ve Wallen, 2006). Bu araştırmada 2019 Türkçe Dersi Öğretim Programının 6. sınıf kazanımları farklı ölçütlere göre tek bir ölçüme dayalı olarak değerlendirildiğinden bu modelin kullanılması tercih edilmiştir.

\section{Çalışma grubu}

Araştırmanın çalışma grubunu 2020-2021 öğretim yılında Türkiye'nin 12 farklı bölgesinde çeşitli üniversitelerde Türkçe Eğitimi Ana Bilim Dalı'nda görev yapmakta olan 35 öğretim üyesi oluşturmaktadır. Araştırmanın çalışma grubunu oluşturan puanlayıcıar (jüriler) belirlenirken üç temel gösterge dikkate alınmıştır. Bunlar; a) Son beş yılda Türkçe Dersi Öğretim Programı́nı kapsayan en az bir derse girmiş olmak, b) Türkçe Dersi Öğretim Programları ile ilgili en az bir bilimsel yayın yapmaktır. Son gösterge ise istatistiki bölge birimleri sınıflandırılmasındaki nüfus, coğrafya, bölgesel kalkınma planları, temel istatistiki göstergeler, illerin sosyo-ekonomik gelişmişlik sıralaması ölçütleri dikkate alınarak 12 ayrı bölgeye ayrılan düzey 1'deki (Türkiye İstatistik Kurumu [TÜiK], 2013) üniversitelerin eğitim fakültelerinde Türkçe eğitimi anabilim dalında görev yapmakta olan öğretim üyeleridir. Düzey 1 'e göre belirlenen bölgelerdeki öğretim üyesi dağılımı tablo 1 de gösterilmiştir.

Tablo 1.

Düzey 1 'e Göre Çalışma Grubunda Yer Alan Öğretim Üyesi Dağılımı

\begin{tabular}{lcc}
\hline Bölge Adı & Düzey 1 Kodlar & Öğretim Üyesi Sayısı \\
\hline İstanbul & TR1 & 3 \\
Batı Marmara & TR2 & 3 \\
Ege & TR3 & 3 \\
Doğu Marmara & TR4 & 3 \\
Batı Anadolu & TR5 & 3 \\
Akdeniz & TR6 & 3 \\
Orta Anadolu & TR7 & 3 \\
Batı Karadeniz & TR8 & 3 \\
Doğu Karadeniz & TR9 & 3 \\
Kuzeydoğu Anadolu & TRA & 3 \\
Ortadoğu Anadolu & TRB & 3 \\
Güneydoğu Anadolu & TRC & 2 \\
\hline
\end{tabular}

\section{Veri Toplama Aracı}

Araştırmada öğretim üyelerini oluşturan puanlayıcıların 6. sınıf Türkçe öğretim programını değerlendirmede kullanacakları değerlendirme formundaki ölçütler; ilgili literatür taraması, programın hedef, içerik, eğitim durumu ve ölçme değerlendirme boyutu dikkate alınarak düzenlenmiştir. Düzenlenen değerlendirme formu son olarak Türkçe öğretim programları alanında uzman 16 öğretim üyesi ve iki ölçme değerlendirme uzmanının görüşleri dikkate alınarak tekrar düzenlenmiştir. Bu doğrultuda geliştirilen değerlendirme formunda 16 ölçüt yer almaktadır. Beşli likert tipinden oluşan ölçütlere verilebilecek yanıtlar birden beşe doğru sırasıyla "Kesinlikle katılmıyorum", "Katılmıyorum", "Orta derecede katılıyorum", "Katılıyorum" ve "Kesinlikle katılıyorum" şeklindedir 


\section{Verilerin Analizi}

Araştırma verileri 6. Sınıf Türkçe Dersi Öğretim Programın 16 ölçüte göre 35 öğretim üyesi tarafından değerlendirmesiyle elde edilmiştir. 6. Sınıf Türkçe Dersi Öğretim Programı'nın değerlendirilmesi çok yüzeyli rasch analiz programı (Linacre, 2014) ile gerçekleştirilmiştir. Bu çerçevede araştırmada program, ölçütler ve puanlayıcılar (jüriler) olmak üzere üç yüzey incelenerek öğretim programı değerlendirilmeye çalışılmıştır.

\section{Araştırma ve Yayın Etiği}

Bu çalışmada "Yükseköğretim Kurumları Bilimsel Araştırma ve Yayın Etiği Yönergesi" kapsamında uyulması belirtilen tüm kurallara uyulmuştur. Yönergenin ikinci bölümü olan "Bilimsel Araştırma ve Yayın Etiğine Aykırı Eylemler" başlığı altında belirtilen eylemlerden hiçbiri gerçekleştirilmemiştir. Katılımcılar araştırma hakkında bilgilendirildikten sonra kendilerine gönüllü onam formu imzalatılmıştır.

\section{Etik Kurul Izni}

Kurul adı = Çanakkale Onsekiz Mart Üniversitesi Lisansüstü Eğitim Enstitüsü

Karar tarihi $=11.03 .2021$.

Belge sayı numarası= E-84026528-050.01.04-2100041447

\section{Bulgular}

Araştırmadan elde edilen veriler çok yüzeyli rasch modeline (ÇYRM) göre analiz edilmiştir. Analizden elde edilen bulgular şekillerle gösterilerek bulgulara yönelik yorumlara yer verilmiştir.

\section{Birinci Alt Amaca Yönelik Bulgular}

Araştırmanın birinci alt amacı "2019 Türkçe Dersi Öğretim Programı 6. sınıf kazanım ölçütlerinin kapsam geçerlik oranları ve kapsam geçerlik indeksleri ne düzeydedir?" şeklindedir. Değerlendirme formundaki ölçütlerin kapsam geçerlik oranları ve indeksleri tablo 2 de gösterilmiştir.

Tablo 2.

Ders kitaplarını Değerlendirme Formu Kapsam Geçerlik Oranları

\begin{tabular}{|c|c|c|c|c|c|}
\hline Boyutlar & $\begin{array}{l}\text { Ölçüt } \\
\text { No }\end{array}$ & Ölçütler & $\mathrm{N}_{\mathrm{G}}$ & KGO & KGi \\
\hline \multirow{5}{*}{$\begin{array}{l}\frac{\bar{d}}{4} \\
\frac{d}{0} \\
\frac{d}{x}\end{array}$} & 1 & $\begin{array}{l}\text { Programın hedefleri ülkenin yetiştirmek istediği } \\
\text { birey profiline uygun şekilde hazırlanmıştır }\end{array}$ & 12 & .76 & \\
\hline & 2 & $\begin{array}{l}\text { Programın hedefleri öğrencilerin ilgi, istek ve } \\
\text { beklentileri dikkate alınarak hazırlanmıştır. }\end{array}$ & 14 & .88 & \multirow[t]{4}{*}{.88} \\
\hline & 3 & $\begin{array}{l}\text { Programın hedefleri konu alanının hedeflerini } \\
\text { kapsamaktadır. }\end{array}$ & 14 & .88 & \\
\hline & 4 & Programın hedefleri öğrenci seviyesine uygundur. & 16 & 1.00 & \\
\hline & 5 & Programın içeriği kazanımlarla uyumludur. & 15 & .90 & \\
\hline \multirow{4}{*}{ 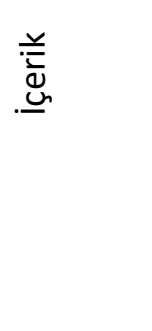 } & 6 & Programın içeriği sarmal bir yapıya sahiptir. & 12 & .74 & \multirow[t]{3}{*}{.88} \\
\hline & 7 & Program içeriği eklektik bir yapıya sahiptir. & 16 & 1.00 & \\
\hline & 8 & $\begin{array}{l}\text { Programın içeriği kazanımlar bakımından } \\
\text { yeterlidir }\end{array}$ & 15 & .90 & \\
\hline & 9 & $\begin{array}{l}\text { Program; yapılandırmacı yaklaşımla örtüşen } \\
\text { stratejilerle uygulanabilir. }\end{array}$ & 15 & .90 & \\
\hline \multirow[t]{2}{*}{ 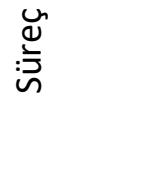 } & 10 & $\begin{array}{l}\text { Program yapılandırmacı yaklaşımla örtüşen } \\
\text { kuramlarla uygulanabilir. }\end{array}$ & 14 & .88 & \multirow[t]{2}{*}{.86} \\
\hline & 11 & $\begin{array}{l}\text { Program, yapılandırmacı yaklaşımla örtüşen } \\
\text { yöntemler uygulanabilir. }\end{array}$ & 14 & .76 & \\
\hline
\end{tabular}



uygundur.

14 Program sonuç temelli ölçme değerlendirmeye 16 uygundur.

15 Program hem süreç hem sonuç temelli ölçme ve 16 değerlendirmeye uygundur.

16 Program alternatif ölçme değerlendirmelere $16 \quad 1.00$ uygundur.

Uzman sayısı:16, Kapsam geçerlik ölçütü: 0.56, Kapsam geçerlik indeksi: \%90, KGO<KGi

Tablo 2 ye göre programdaki kazanımların 16 ölçüt ile değerlendirildiği görülmektedir. Ölçütlerin kapsam geçerlik oranları $\mathrm{KGO}_{\text {madde }}=(\mathrm{NG} / \mathrm{N} / 2)-1$ formülü ile (Şencan, 2005) .56 olarak hesaplanmıştır. Kapsam geçerlik indeksi (KGi) ise KGO toplamının ölçüt sayısını bölünmesi ile (Yurdagül ve Aşkar, 2008) elde edilerek .90 olarak hesaplanmıştır. Elde edilen bu değerler puanlayıcıların değerlendirmelerinin istatistiksel olarak manidar bir farklılık oluşturduğunu göstermektedir (Veneziano ve Hooper, 1997).

\section{İkinci Alt Amaca Yönelik Bulgular}

Araştırmanın ikinci alt amacı "2019 Türkçe Dersi Öğretim Programı 6. sınıf kazanımlarının çok yüzeyli rasch modeli ile incelenmesi sonucundaki logit değerleri ve veri kalibrasyon haritasında dağılım nasıldır" şeklindedir. Ölçütler, puanlayıcı ve programa ilişkin değişken haritası yönelik bulgular şekil 1 de gösterilmiştir.

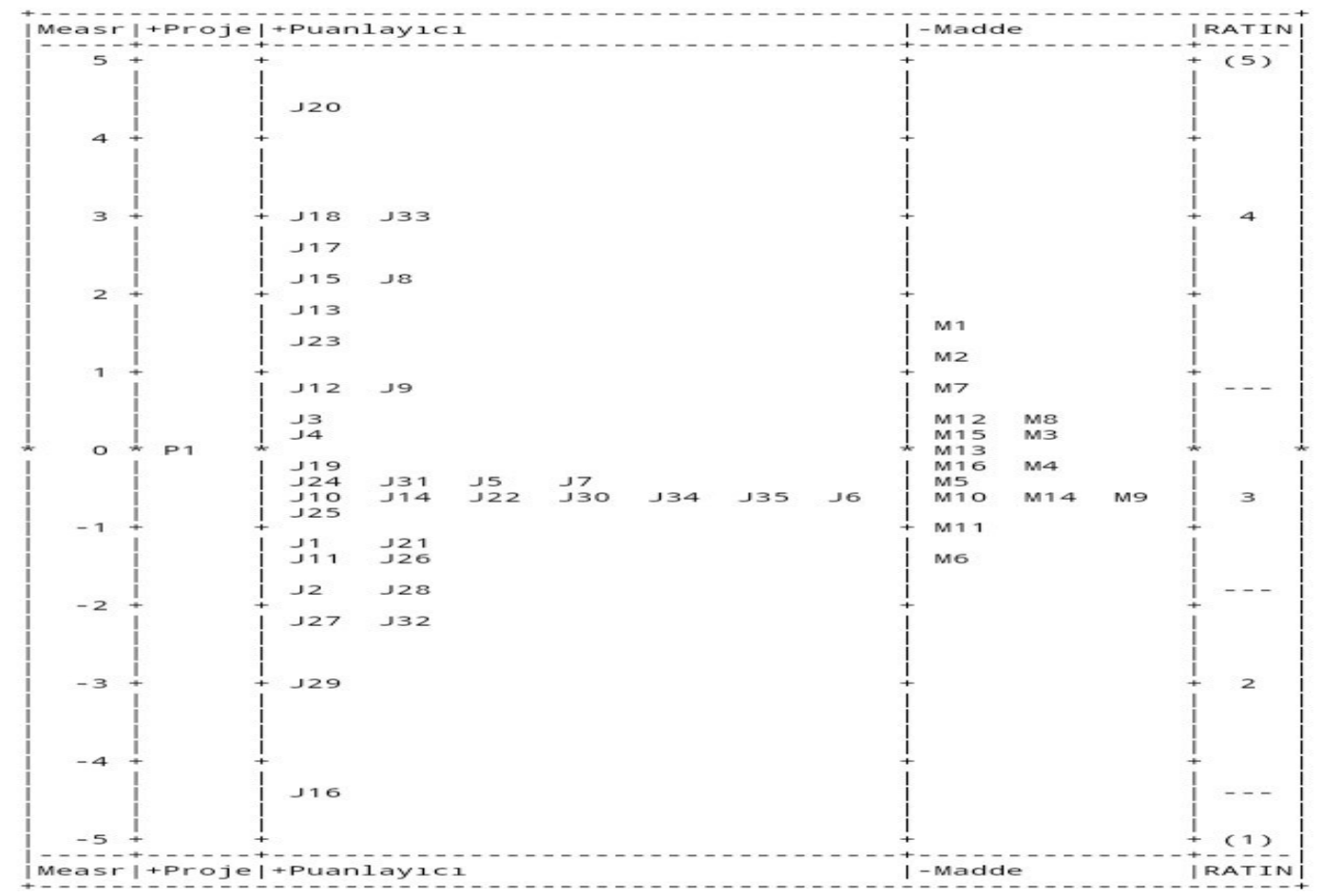

Şekil 1. Veri Kalibrasyon Haritası.

Şekil 1'deki veri kalibrasyon haritasında proje; 2019 Türkçe Dersi Öğretim Programı 6. sınıf kazanımları, puanlayıcı; programı değerlendiren öğretim üyelerini, maddeler ise değerlendirme ölçütlerini tanımlamaktadır. Veri kalibrasyon haritasına göre öğretim programının değerlendirildiği ölçütler incelendiğinde altıncı madde "Programın içeriği sarmal bir yapıya sahiptir." ve on birinci maddelerin "Programda, yapılandırmacı yaklaşımla örtüşen yöntemler uygulanabilir." zor maddeler (ölçütler) olduğu buna karşın birinci madde "Programın hedefleri ülkenin yetiştirmek istediği birey 
profiline uygun şekilde hazırlanmıştır", ikinci madde "Programın hedefleri öğrencilerin ilgi, istek ve beklentileri dikkate alınarak hazırlanmıştır." ve yedinci maddelerin " Program içeriği eklektik bir yapıya sahiptir." ise kolay maddeler (ölçütler) olduğu dikkat çekmektedir. Bununla birlikte puanlayıcılardan en cömert olanlarının yirmi, on sekiz ve otuz üç numaralı puanlayıcılar olduğu, en katı eğilim gösteren puanlayıcıların ise, on altı ve yirmi dokuz numaralı puanlayıcılar olduğu saptanmıştır.

\section{Üçüncü Alt Amaca Yönelik Bulgular}

Araştırmanın üçüncü alt amacını "2019 Türkçe Dersi Öğretim Programı 6. sınıf kazanımlarını puanlayan puanlayıcıların katılık/cömertliklerine ait istatistiksel bilgileri hangi düzeydedir" şeklindeki soru oluşturmaktadır. Öğretim programını puanlayan puanlayıcıların katılık/cömertliklerine ait istatistiksel bilgiler tablo 2'de belirtilerek ve bu bilgilere yönelik yorumlar yapılmıştır.

Tablo 3.

Puanlayıcıların Puanlama Performanslarına İlişkin Ölçüm Raporu

\begin{tabular}{|c|c|c|c|c|c|c|c|c|c|}
\hline \multirow[t]{2}{*}{ Puanlayıcı } & \multirow{2}{*}{$\begin{array}{c}\text { T. } \\
\text { Puan }\end{array}$} & \multirow{2}{*}{$\begin{array}{c}\text { Gözlem } \\
\text { Ort. }\end{array}$} & \multirow{2}{*}{$\begin{array}{l}\text { Düzelt. } \\
\text { Ort. }\end{array}$} & \multicolumn{2}{|c|}{ Model } & \multicolumn{2}{|c|}{ Uyum içi } & \multicolumn{2}{|c|}{ Uyum Dışı } \\
\hline & & & & Ölçüm & $\mathrm{SE}$ & $\begin{array}{c}\mathrm{MnS} \\
\mathrm{q}\end{array}$ & ZStd & $\mathrm{MnSq}$ & ZStd \\
\hline$J 20$ & 68 & 4.25 & 4.23 & 4.31 & .55 & 2.09 & 2.5 & 2.16 & 2.4 \\
\hline J18 & 64 & 4.00 & 4.00 & 2.96 & .60 & 1.25 & .6 & 1.33 & .7 \\
\hline $\mathrm{J} 33$ & 64 & 4.00 & 4.00 & 2.96 & .60 & .10 & -2.9 & .8 & -2.9 \\
\hline J17 & 63 & 3.94 & 3.94 & 2.61 & .59 & .21 & -2.1 & .15 & -2.4 \\
\hline J8 & 62 & 3.88 & 3.89 & 2.29 & .56 & .28 & -1.9 & .20 & -2.2 \\
\hline $\mathrm{J} 15$ & 62 & 3.88 & 3.89 & 2.29 & .56 & .28 & -1.9 & .20 & -2.2 \\
\hline j13 & 60 & 3.75 & 3.78 & 1.72 & .51 & .82 & -.3 & .61 & -.8 \\
\hline$J 23$ & 59 & 3.69 & 3.72 & 1.47 & .49 & 1.80 & 1.7 & 2.14 & 2.1 \\
\hline J9 & 56 & 3.50 & 3.53 & .83 & .44 & 1.49 & 1.3 & 1.72 & 1.7 \\
\hline $\mathrm{J} 12$ & 56 & 3.50 & 3.53 & .83 & .44 & 1.61 & 1.6 & 1.35 & 1.0 \\
\hline $\mathrm{J3}$ & 54 & 3.38 & 3.40 & .46 & .42 & .42 & -2.1 & .44 & -2.0 \\
\hline$J 4$ & 52 & 3.25 & 3.27 & .12 & .41 & 1.76 & 2.0 & 1.73 & 1.9 \\
\hline J19 & 50 & 3.13 & 3.14 & -.20 & .40 & 1.14 & .5 & 1.13 & .5 \\
\hline $\mathrm{J} 5$ & 49 & 3.06 & 3.07 & -.36 & .39 & .73 & -.8 & .72 & -.8 \\
\hline $\mathrm{J} 7$ & 49 & 3.06 & 3.07 & -.36 & .39 & .89 & -.2 & .88 & -.2 \\
\hline$J 24$ & 49 & 3.06 & 3.07 & -.36 & .39 & .51 & -1.7 & .51 & -1.7 \\
\hline $\mathrm{J} 31$ & 49 & 3.06 & 3.07 & -.36 & .39 & .39 & -2.4 & .39 & -2.3 \\
\hline $\mathrm{J} 6$ & 48 & 3.00 & 3.01 & -.51 & .39 & .57 & -1.4 & .57 & -1.4 \\
\hline $\mathrm{J} 14$ & 48 & 3.00 & 3.01 & -.51 & .39 & 1.15 & .5 & 1.14 & .5 \\
\hline $\mathrm{J} 22$ & 48 & 3.00 & 3.01 & -.51 & .39 & .56 & -1.5 & .57 & -1.5 \\
\hline $\mathrm{J} 30$ & 48 & 3.00 & 3.01 & -.51 & .39 & .41 & -2.2 & .42 & -2.2 \\
\hline J34 & 48 & 3.00 & 3.01 & -.51 & .39 & .57 & -1.4 & .57 & -1.4 \\
\hline $\mathrm{J} 35$ & 48 & 3.00 & 3.01 & -.51 & .39 & .57 & -1.4 & .57 & -1.4 \\
\hline $\mathrm{J} 10$ & 47 & 2.94 & 2.94 & -.66 & .39 & 1.01 & .1 & 1.01 & .1 \\
\hline $\mathrm{J} 25$ & 46 & 2.88 & 2.88 & -.81 & .39 & .75 & -.7 & .80 & -.5 \\
\hline $\mathrm{J} 1$ & 43 & 2.69 & 2.69 & -1.26 & .39 & 1.56 & 1.5 & 1.55 & 1.5 \\
\hline$J 21$ & 43 & 2.69 & 2.69 & -1.26 & .39 & .81 & -.5 & .83 & -.4 \\
\hline $\mathrm{J} 11$ & 42 & 2.63 & 2.62 & -1.41 & .39 & 1.62 & 1.6 & 1.60 & 1.6 \\
\hline $\mathrm{J} 26$ & 42 & 2.63 & 2.62 & -1.41 & .39 & 1.67 & 1.7 & 1.70 & 1.8 \\
\hline $\mathrm{J} 2$ & 40 & 2.50 & 2.49 & -1.72 & .39 & 2.54 & 3.3 & 2.52 & 3.2 \\
\hline $\mathrm{J} 28$ & 40 & 2.50 & 2.49 & -1.72 & .39 & .57 & -1.4 & .56 & -1.4 \\
\hline $\mathrm{J} 27$ & 37 & 2.31 & 2.31 & -2.19 & .40 & .44 & -1.9 & .42 & -2.0 \\
\hline $\mathrm{J} 32$ & 37 & 2.31 & 2.31 & -2.19 & .40 & .44 & -1.9 & .42 & -2.0 \\
\hline$J 29$ & 32 & 2.00 & 2.00 & -3.01 & .42 & 1.48 & 1.2 & 1.44 & 1.2 \\
\hline
\end{tabular}


116

$25 \quad 1.56$

1.55

$-4.33$

.46

$1.77 \quad 2.0$

1.65

1.8

Model, Sample: RMSE .44 Adj (True) S.D. 1.74 Separation 3. 94 Strata 5.59 Reliability (not inter-

.94 Model, Fixed (all same) chi-square: 462.3 d.f.: 34 significance (probability): .00

Tablo 3 de araştırmada puanlayııların belli ölçütlere göre programdaki kazanımlara yönelik değerlendirmeleri ayrıntılı olarak gösterilmiştir. Bu bulguya göre, puanlayıcılar arasında en cömert olan "Jüri 20" kodlu puanlayıcının olduğu söylenebilir. Puanlamalar sırasında en katı puanlama sergileyen puanlayııının ise "Juri16" kodlu puanlayıcının olduğu yine tablo 2'deki bulgulardan anlaşılmaktadır. Puanlayıcıların yapmış oldukları puanlamalara ilişkin olarak aşırı uçlar haricindeki tüm veri için hesaplanan standart hata değeri olan RMSE değeri ise 1.74 şeklinde hesaplanmıştır. Puanlayıcıların puanlama performanslarına ilişkin güvenirlik katsayısı ise 0.94 olarak hesaplanmıştır. Bu değere göre, puanlayıcıların yüksek bir güvenirlik puanlama değeri ile puanlamalarını gerçekleştirdikleri söylenebilir. Ayrıca puanlayıcıların puanlamalara ilişkin ayırma indeksi 3.22 ve güvenirlik katsayısı ise 0.91 ile sabit etkiye ait "Puanlayıcıların katılık/cömertlikleri açısından aralarında anlamlı bir fark yoktur" hipotezi kay-kare testi ile sınandığında $\left(X^{2}(34)=462.3, p<.05\right)$ yokluk hipotezi reddedilmiştir. Buna göre, puanlayıcıların katılık/cömertlik düzeyleri açısından kendi aralarında istatistiksel olarak anlamlı bir fark olduğu söylenebilir. Bu çerçevede puanlayıcılar programdaki kazanımları değerlendirme konusunda tutarlı puanlayıcı davranışına sahip oldukları söylenebilir.

\section{Dördüncü Alt Amaca Yönelik Bulgular}

Araştırmanın dördüncü alt amacını "2019 Türkçe Dersi Öğretim Programı 6. sınıf kazanımlarının değerlendirildiği ölçütlere ilişkin ölçüm raporu nasıldır?" şeklindeki soru oluşturmaktadır. Öğretim programının değerlendirildiği ölçütlere ilişkin ölçüm raporları tablo 3 de verilmiş ve ölçüm raporlarına ilişkin bulguların yorumlarına yer verilmiştir.

Tablo 4.

Değerlendirme Ölçütlerine iliş̧kin Ölçüm Raporu

\begin{tabular}{|c|c|c|c|c|c|c|c|c|c|}
\hline \multirow[t]{2}{*}{ Ölçütler } & \multirow{2}{*}{$\begin{array}{l}\text { T. } \\
\text { Puan }\end{array}$} & \multirow{2}{*}{$\begin{array}{l}\text { Gözlem } \\
\text { Ort. }\end{array}$} & \multirow{2}{*}{$\begin{array}{l}\text { Düzeltmş } \\
\text { Ort. }\end{array}$} & \multicolumn{2}{|c|}{ Model } & \multicolumn{2}{|c|}{ Uyum İçi } & \multicolumn{2}{|c|}{ Uyum Dışı } \\
\hline & & & & Ölccum & SE & $\mathrm{MnSq}$ & ZStd & $\mathrm{MnSa}$ & ZStd \\
\hline Ö1 & 89 & 2.54 & 2.54 & 1.51 & .28 & 1.08 & .4 & 1.04 & .2 \\
\hline Ö2 & 93 & 2.66 & 2.67 & 1.19 & .28 & .89 &.-4 & .96 & .0 \\
\hline Ö7 & 98 & 2.80 & 2.84 & .8 & .28 & 1.17 & .7 & 1.08 & .4 \\
\hline Ö12 & 102 & 2.91 & 2.97 & .49 & .28 & 1.23 & .9 & 1.21 & .8 \\
\hline Ö8 & 103 & 2.94 & 3.00 & .41 & .28 & 1.02 & .1 & .98 & .0 \\
\hline Ö3 & 106 & 3.03 & 3.10 & .18 & .28 & 1.01 & .1 & 1.05 & .2 \\
\hline Ö15 & 106 & 3.03 & 3.10 & .18 & .28 & .35 & -3.6 & .34 & -3.4 \\
\hline Ö13 & 107 & 3.06 & 3.14 & .10 & .28 & .63 & -1.7 & .59 & -1.8 \\
\hline Ö4 & 110 & 3.14 & 3.23 & -.14 & .29 & 1.49 & 1.8 & 1.44 & 1.5 \\
\hline Ö16 & 110 & 3.14 & 3.23 & -.14 & .29 & .76 & -1.0 & .79 & -.8 \\
\hline Ö5 & 113 & 3.23 & 3.33 & -.39 & .29 & 1.41 & 1.6 & 1.46 & 1.6 \\
\hline Ö9 & 115 & 3.29 & 3.39 & -.56 & .29 & .77 & -.9 & .73 & -1.0 \\
\hline Ö14 & 115 & 3.29 & 3.39 & -.56 & .29 & .89 & -.3 & .83 & -.6 \\
\hline Ö10 & 116 & 3.31 & 3.42 & -.64 & .29 & .72 & -1.2 & .62 & -1.6 \\
\hline Ö11 & 120 & 3.43 & 3.54 & -.98 & .30 & 1.39 & 1.5 & 1.46 & 1.6 \\
\hline Ö6 & 125 & 3.57 & 3.68 & -1.44 & .31 & 1.06 & .3 & 1.00 & .1 \\
\hline
\end{tabular}

Model, Sample: RMSE .29 Adj (True) S.D. 70 Separation 2. 43 Strata 3.57 Reliability .86

Model, Fixed (all same) chi-square: 108.2 d.f.: 15 significance (probability): .00

Tablo 4 de değerlendirme ölçütlerine ilişkin ayrıntılı ölçüm raporu verilmiştir. Tablo 4'te verilen analizler incelendiğinde, 6 . sınıf Türkçe öğretim programının "Ö${ }_{1}$ " kodlu ölçüt olan "Programın hedefleri ülkenin yetiştirmek istediği birey profiline uygun şekilde hazırlanmıştır" ve "Ö ${ }_{2}$ " kodlu ölçüt olan 
"Programın hedefleri öğrencilerin ilgi, istek ve beklentileri dikkate alınarak hazırlanmıştır" ölçütü ile "Ö7" kodlu "Program içeriği eklektik bir yapıya sahiptir" ölçütleri öğretim elemanları tarafından 6. sınıf Türkçe öğretim programda yer alan en zayıf ölçütler olarak değerlendirilmiştir. 6. sınıf Türkçe öğretim programındaki "Ö 6 " kodlu "Program sarmal bir yapıya sahiptir" ve "Ö ${ }_{11}$ " kodlu "Programda, yapılandırmacı yaklaşımla örtüşen yöntemler uygulanabilir" ile "Programda yapılandırmacı yaklaşımla örtüşen kuramlar uygulanabilir" ölçütleri ise öğretim elemanları tarafından programda yer alan en güçlü ölçütler şeklinde belirlenmiştir. Öğretim programının değerlendirme ölçütlerine ilişkin standart hata değeri ise (RMSE=.29) şeklinde belirlenmiştir. Bu hata değeri dikkate alınarak hesaplanan düzetilmiş standart sapma değeri de .70 şeklinde hesaplanmıştır. Bu değer, referans değer olarak kabul edilen $1.0^{\prime}$ in altındadır. Öğretim programının değerlendirildiği ölçütlerle ilgili güvenirlik katsayısı .86 şeklinde hesaplanmıştır. Bu bulguya göre, 6 . sınıf Türkçe öğretim programının değerlendirilmesiyle ilgili ölçütler iyi düzeyde güvenirliğe sahip olduğu düşünülebilir.

Tablo 4'teki değerlendirme ölçütlerine ait ayırma indeksi de verilmiş ve bu değer 2.43 olarak hesaplanmıştır. Ölçütlere ilişkin ayırma indeksi ve güvenirlik katsayısı 0.86 ile sabit etkiye ait "öğretim elemanlarının programın niteliğini belirlemede kullanılan ölçütlerin güçlükleri açısından anlamlı farklılık yoktur" hipotezi kay-kare ile sınandığında $\left(X^{2}{ }_{(15)}=108.2, p<.05\right)$ yokluk hipotezi reddedilmiştir. Bu bulguya göre, öğretim elemanları tarafından programdaki kazanımları değerlendirmek için kullanılan ölçütlerin, programa ait özellikleri ölçebildiği düşünülebilir. Ayrıca bu ölçütleri karşılamaları ile ilgili güçlük düzeyleri açısından da istatistiksel olarak anlamlı farkın olduğu söylenebilir.

\section{Tartışma, Sonuç ve Öneriler}

Bu araştırmada 2019 Türkçe Dersi Öğretim Programı 6. sınıf kazanımları Türkçe ğitimi Anabilim Dalı'ndaki öğretim üyeleri tarafından değerlendirilmiştir. Bu çerçevede öğretim programının kazanımları, puanlamayı oluşturan puanlayıcıların katılık/cömertlikleri ve araştırmada kullanılan " 6 . sınıf Türkçe öğretim programı kazanımları değerlendirme formu" çok yüzeyle Rasch analiz modeli aracılı̆̆ıla incelenmiştir. Araştırmada dikkat çeken unsurlardan biri öğretim programını değerlendirmek amacı ile belirlenen ölçütlerin kolaylık ve zorluk bakımından değerlendirilmesidir. Araştırmadan elde edilen bulgular dikkate alındığında öğretim üyeleri tarafından 6. sınıf Türkçe Dersi Öğretim Programı'nda en fazla zorlandıkları ölçütlerin $\left[\mathrm{M}_{1}\right],\left[\mathrm{M}_{2}\right]$ ve $\left[\mathrm{M}_{7}\right]$ kodlu ölçütler olduğu ortaya çıkmıştır. Bu bağlamda öğretim üyelerinin "Programın hedefleri ülkenin yetiştirmek istediği birey profiline uygun şekilde hazırlanmıştır.", "Programın hedefleri öğrencilerin ilgi, istek ve beklentileri dikkate alınarak hazırlanmıştır." ve "Program içeriği eklektik bir yapıya sahiptir." şeklindeki ölçütlere katılmadıkları söylenebilir. Bu çerçevede 6. Sınıf Türkçe Dersi Öğretim Programı'nın kazanımlarının ülkenin yetiştirmek istediği birey profilini ve eğitim programının uzak hedeflerini beklenen düzeyde karşılamadığı söylenebilir. Bununla birlikte programın öğrencilerin ilgi, istek ve beklentilerini de karşılayamadığı katılımcılar tarafından belirtilen diğer bir noktadır. Bir başka nokta ise programının hedef kaynaklarından biri olarak tanımlanan bireysel ihtiyaçları karşılamada da eksik kaldığının katılımcılar tarafından belirtilmesidir. Ayrıca katılımcıların öğretim programının bireyin eğitim sürecinde ihtiyaçlarını karşılamak amacıyla farklı öğrenme kuram ve modellerdeki uygulamaları dikkate alınarak düzenlendiği ölçütüne de katılmadıkları ortaya çıkmaktadır. Sandıkçı (2006) Türkçe öğretim programının uygulamalarıyla ilgili yaptığı araştırmada öğrencilerin Türkçe derslerine karşı ilgisiz oldukları belirtilmiştir. Benzer şekilde Kayhan, Altun ve Gürol (2019) tarafından Türkçe öğretim programının yönelik öğretmen görüşlerine göre değerlendirildiği araştırmada öğrencilerden kaynaklı sorunların programın işlevselliğini etkilediğine işaret edilmiştir. Direkçi, Akbulut ve Şimşek (2019) ise Türkçe öğretim programının dijital okuryazarlık gibi çağın koşullarını dikkate alan farklı modelleri içermede eksik kaldığına dikkat çekmişlerdir. Ayrıca kazanımların öğrencilerin yaratıcıığını olumlu yönde etkilemediği araştırmada vurgulanan diğer bir unsurdur. Nitekim Çerçi (2018) Türkçe öğretim programında analiz etmek, değerlendirmek ve yaratmak gibi üst bilişsel bilgi türüne yönelik kazanımların belirtilmediğini bu durumun öğrenmenin niteliğini ve kalıcılığını olumsuz etkilediğini ifade etmiştir. İşeri (2007), Epçaçan ve Erzen (2008) 'in öğretmenlerle gerçekleştirdikleri çalışmalarda da benzer sonuçlara ulaşıımıştır. Bu araştırmalarda araştırmacılar, 6. sınıf Türkçe öğretim programının kazanımlarının programın amacını beklenen düzeyde karşılayamadığını belirtmişlerdir. Mutlu ve Yurt 
(2019)'un gerçekleştirdikleri araştırmada da Türkçe öğretim programındaki kazanım alanlarının dengeli bir şekilde dağılmadığı vurgulanmıştır. Karadağ (2012) de programdaki bazı kazanımların hedeflenen düzeyde gerçekleştirilemediği bulgusuna ulaşmıştır. Arı (2017) programdaki kazanımların muğlak ifadeler içerdiği ve kazanımların sınıflara dağılımında sorunlar olduğunu vurgulamıştır. Benzer şekilde, Altunkeser ve Coşkun (2016) ise programdaki eksikliklerin giderilmesinde konu alanı uzmanlarının ve öğretmenlerin katılımlarının ve önerilerinin daha fazla dikkate alınması gerektiğini belirtmişlerdir. Öğretim programlarının kazanımlarının öğrenciler tarafından benimsenmesinde, öğrencilerde ilgi ve istek uyandırmada onların güdülenmelerine katkıda bulunmada ders kitapları başat öneme sahiptir (Göçer, 2007). Matematik ve Fen araştırması (TIMMS) ve Uluslararası Öğrenci Değerlendirme Programı (PISA) gibi uluslararası testler eğitim politikaları ve reformlarını etkileyen önemli bir öğe olarak ortaya çıkmaktadır (OECD 2011). Bu sınavlar öğrencilerin üst bilişsel alan ile günlük yaşamda karşılaştıkları problemleri çözme becerilerini ölçmektedir (Gronmo ve Olsen 2006). Bu sınavlarda Türk öğrencilerin daha yüksek başarı göstermelerini destekleyecek önemli noktalardan biri de Türkçe öğretim programındaki kazanımlarda çağın gereksinimlerinin dikkate alınması, üst bilişsel alandaki becerilere ağırlıklı olarak yer verilmesi olabilir.

Araştırmadaki diğer bir önemli bulgu ise puanlayıcıların $\left[M_{6}\right]$ ve $\left[M_{11}\right]$ kodlu ölçütleri kolay ölçütler şeklinde değerlendirmeleridir. Bu doğrultuda puanlayıcıların "Programın içeriği sarmal bir yapıya sahiptir." ile "Programda yapılandırmacı yaklaşımla örtüşen yöntemler uygulanabilir" ölçütlerine katıldıkları yönünde görüş belirttikleri ortaya çıkmaktadır. Program içeriğinin sarmal yapıya sahip olduğu bulgusu Aydın ve Aydın (2020) ile Arı (2017) tarafından gerçekleştirilen araştırma bulgularıyla da desteklenmektedir. Sarmal programlama yaklaşımı özellikle dil öğretim programlarında konuların yeri ve zamanı geldikçe tekrarlar aracılığıyla öğretilmesinde etkili olarak kullanılmaktadır (Brooks, 2010). Nitekim Türkçe öğretim programlarında farklı konu ve sınıf düzeylerinde sarmal bir yaklaşımla tekrar eden kazanımlara (Millî Eğitim Bakanlığı [MEB], 2019) yer verildiği vurgulanmıştır. 6. sınıf Türkçe öğretim programındaki kazanımlarını gerçekleştirmede yapılandırmacı yaklaşımla örtüşen yöntemlerin uygulanabileceği ise birçok araştırmacının güncel çalışmaları ile vurgulanmıştır (Altunkeser ve Coşkun, 2016; Arı, 2017; Aydın ve Aydın, 2020; Kahtalı ve Çelik, 2020; Kayhan, Altun ve Gürol, 2019). Yapılandırmacı yaklaşım, öğrenenin etkin ve öğrendiklerini deneyimlerine bağlı olarak inşaa etmeyi, sorgulamayı ve düzenlemeyi amaçlamaktadır (Brooks ve Brooks, 1999). Bu yaklaşımda öğrenci etkin, yaratıcı ve sosyal bir öğrenen olmak üzere üç belirgin rol üstlenmektedir (Philips, 1995). Nitekim 1739 sayılı Millî Eğitim Temel Kanunu'nda ifade edilen Türk Millî Eğitiminin Genel Amaçları ve Temel ilkeleri doğrultusunda hazırlanan Türkçe Dersi Öğretim Programı'nda öğrencilere kazandırılması beklenen özelliklerden biri de bilgiyi araştırma, keşfetme ve zihinde yapılandırma becerilerini geliştirmektedir (MEB, 2019). Yapılandırmacı yaklaşımın dört temel özelliği öz düzenlemeli öğrenme, yansıtma, deneyimleyerek öğrenme ve öğrenmeyi öğrenme şeklinde tanımlanmaktadır (Huang, 2002). Bu unsurların 6. sınıf Türkçe öğretim programında çeşitli yöntemlerle uygulanabilir olduğu söylenebilir.

Bu araştırmada en yüksek düzeyde katı ve cömert puanlama gerçekleştirerek yanlııık sergileyen puanlayıcılar dikkate alındığında $J_{16}$ nolu puanlayıcının öğretim programının kazanımlarını değerlendirirken katı bir davranış sergilediği belirlenmiştir. Buna karşın $\mathrm{J}_{20}$ nolu puanlayıcının öğretim programının kazanımlarını değerlendirmede cömert davranış sergilediği belirlenmiştir.

Araştırmada öğretim üyelerinin programın uzak hedeflerine ve eklektik yapısına yönelik eksiklikler olduğuna yönelik görüş belirttikleri ortaya çıkmıştır. Bu bağlamda programın bu çerçevelerde farklı paydaşların görüşleri alınarak tekrar incelenerek değerlendirilmesi düşünülebilir. Bu araştırmada ölçütler, 6 . sınıf Türkçe öğretim programı ve puanlayıcılara ait yüzeyler dikkate alınmıştır. Dördüncü bir yüzey olarak öğretmenler de araştırmaya eklenebilir. 2019 Türkçe Dersi Öğretim Programı 6. sınıf kazanımları öğretmenlerin görüşlerinin de dikkate alındığı karma bir araştırma ile detaylı şekilde incelenebilir.

\section{Araştırma ve Yayın Etiği}

Bu çalışmada "Yükseköğretim Kurumları Bilimsel Araştırma ve Yayın Etiği Yönergesi" kapsamında uyulması belirtilen tüm kurallara uyulmuştur. Yönergenin ikinci bölümü olan "Bilimsel Araştırma ve Yayın Etiğine Aykırı Eylemler" başlığı altında belirtilen eylemlerden hiçbiri 
gerçekleştirilmemiştir. Katılımcılar araştırma hakkında bilgilendirildikten sonra kendilerine gönüllü onam formu imzalatılmıştır.

\section{Etik Kurul izni}

Kurul adı = Çanakkale Onsekiz Mart Üniversitesi Lisansüstü Eğitim Enstitüsü

Karar tarihi=11.03.2021.

Belge sayı numarası= E-84026528-050.01.04-2100041447

\section{Yazarların Katkı Oranı}

Bu çalışma tek yazarlı olarak yazılmıştır.

\section{Çıkar Çatışması}

Bu çalışmada çıkar çatışmasına neden olabilecek bir husus yoktur.

\section{Kaynaklar}

Akar, Z. (2019). Sekizinci sınıf Türkçe dersi yazılı sınav sorularının merkezi sınav Türkçe soruları ile karşılaştırılması (Yayımlanmamış yüksek lisans tezi). Atatürk Üniversitesi Eğitim Bilimleri Enstitüsü Türkçe ve Sosyal Bilimler Eğitimi Ana Bilim Dalı, Erzurum.

Altunkeser, F. ve Coşkun, i. (2016). 2009 ve 2015 Türkçe dersi öğretim programlarının karşılaştırılması ve değerlendirilmesi. Trakya Üniversitesi Eğitim Fakültesi Dergisi, 8 (1), 114-133.

Arı, G. (2017). Türkçe dersi öğretim programındaki (ortaokul) okuma kazanımlarının değerlendirilmesi. Ana Dili Eğitimi Dergisi, 5(4), 685-703.

Aslan, M. ve Atik, U. (2018). 2015 ve 2017 ilkokul Türkçe dersi öğretim programı kazanımlarının revize edilmiş Bloom Taksonomisine göre incelenmesi. Uluslararası Türkçe Edebiyat Kültür Eğitim Dergisi, 7(1), 528-547.

Atik, S. ve Aykaç, N. (2017). 2009 ve 2015 Türkçe öğretim programlarının eğitim programı ögeleri açısından değerlendirilmesi. Ahi Evran Üniversitesi Kırşehir Eğitim Fakültesi Dergisi, 18 (3), 586607.

Avcı, i. N. (2018). Türkçe öğretim programı 2018 bağlamında 5. sınıf Türkçe dersi öğretimine ilişkin ögrretmen ve öğrenci görüşlerinin incelenmesi. (Yayımlanmamış yüksek lisans tezi). Akdeniz Üniversitesi Eğitim Bilimleri Enstitüsü Türkçe ve Sosyal Bilimler Eğitimi Anabilim Dalı, Antalya.

Aydın, i ve Aydın, G. (2020). 2018 Türkçe dersi öğretim programı bağlamında 5, 6, 7 ve 8. sınıf Türkçe ders kitaplarındaki söz varlığına yönelik etkinliklerin sözcük öğretimi açısından incelenmesi. ODÜ Sosyal Bilimler Araştırmaları Dergisi, 10 (1), 1-23.

Belet Boyacı, Ş. D. ve Güner Özer, M. (2019). Öğrenmenin geleceği: 21. Yüzyıl becerileri perspektifiyle Türkçe dersi öğretim programları. Anadolu Journal of Educational Sciences International 9(2), 708-738.

Brooks, M. G., \& Brooks, J. G. (1999). The Courage to be constructivist. Educational Leadership, 57(3), 18-24.

Brooks, N.J. (2010). Spiral curriculum encyclopedia of curriculum studies. (Ed.: Crag Kridel). p:808-809. California: Sage Publication.

Büyükarslan, Z. (2011). Ilköğretim dördüncü ve beşinci sınıf Türkçe ders kitaplarında yer alan metin etkinliklerinin eleştirel düşünme becerileriyle örtüşme düzeyi. (Yayımlanmamış yüksek lisans tezi). Atatürk Üniversitesi Eğitim Bilimleri Enstitüsü IIlköğretim Ana Bilim Dalı, Erzurum.

Çerçi, A. (2018). 2018 Türkçe dersi öğretim programı kazanımlarının (5, 6, 7, 8. sınıf) yenilenen Bloom Taksonomisine göre incelenmesi. Okuma Yazma Eğitimi Araştırmaları, 6 (2), 70-81.

Dilidüzgün, Ş. (2009). Yapılandırmacı yaklaşımla hazırlanan ilköğretim Türkçe öğretim programı ve ders kitaplarında metin-odaklı görevlerin yeri. Sakarya Üniversitesi Eğitim Fakültesi Dergisi, 17, 274290.

Direkçi, B., Akbulut, S. ve Şimşek, B. (2019). Türkçe dersi öğretim programı (2018) ve ortaokul Türkçe ders kitaplarının dijital okuryazarlık becerileri bağlamında incelenmesi. Avrasya Uluslararası Araştırmalar Dergisi, 7(16), 797-813. 
Direkçi, B., Şimşek, B. ve Uygun, M. (2020). Türkçe öğretmenlerinin Türkçe dersi öğretim programında (2019) yer alan okuryazarlık becerilerinin kazandırılmasına ilişkin görüşlerinin incelenmesi. Eğitimde Yeni Yaklaşımlar Dergisi, 3 (1), 34-49.

Doğu, Y. (2010). Ilköğretim altıncı sınıf Türkçe dersi öğrenci çalışma kitabındaki etkinliklerin uygulanabilirliğinin öğretmen görüşleri doğrultusunda değerlendirilmesi Aksaray örneği. (Yayımlanmamış yüksek lisans tezi). Selçuk Üniversitesi Sosyal Bilimler Enstitüsü Türkçe Eğitimi Anabilim Dalı, Konya.

Epçaçan, C. ve Erzen, M. (2008). İlköğretim Türkçe dersi öğretim programının değerlendirilmesi. Uluslararası Sosyal Araştırmalar Dergisi, 1(4), 183-202.

Er, O. (2011). Illköğretim sekizinci sınıf Türkçe dersi öğretim programı dinleme/izleme alanının öğretmen görüşleri doğrultusunda değerlendirilmesi. (Yayımlanmamış yüksek lisans tezi). Çukurova Üniversitesi Sosyal Bilimler Enstitüsü İlköğretim Anabilim Dalı, Adana.

Fraenkel, J. R., \& Wallen, N., E. (2006). How to design and evaluate research in education. New York: McGraw-Hill.

Girgin, Y. (2011). Cumhuriyet dönemi (1929-1930,1949,1981) ortaokul Türkçe öğretimi programlarının içerik, genel ve özel amaçlarıyla karşılaştırmalı gelişim düzeyi. Adnan Menderes Üniversitesi Eğitim Fakültesi Eğitim Bilimleri Dergisi, 2(1), 11-26.

Göçer, A. (2007). Türkçenin yabancı dil olarak öğretiminde kullanılan ders kitaplarının ölçme ve değerlendirme açısından incelenmesi. Dil Dergisi, 137, 30- 48.

Gronmo, L. S., \& Olsen, R. V. (2006). TIMSS versus PISA: The case of pure and applied mathematics. 2nd IEA International Research Conference, Washington, DC.

Huang, H. M. (2002). Towards constructivism for adult learners in online learning environments. British Journal of Educational Technology, 33, 27-37

İşeri, K. (2007). Altıncı sınıf Türkçe ders kitabının ilköğretim Türkçe programının amaçlarına uygunluğunun değerlendirilmesi. Dil Dergisi, 62, 136.

Kahtalı, B.D. ve Çelik, Ş. (2020). 2019 Türkçe öğretim programında ölçme ve değerlendirme ile Türkçe öğretmenlerinin ölçme ve değerlendirme araçlarını kullanma düzeyleri, Eğitimde Kuram ve Uygulama Araştırmaları Dergisi, 6 (2), 237-244.

Karadağ, Ö. (2012). Anlama becerileri açısından Türkçe dersi öğretim programı (6, 7, 8. Sınıflar)’na eleştirel bir bakış. CÜ Sosyal Bilimler Dergisi, 36 (1), 98-110.

Karakoç Öztürk, B. (2008). Ilköğretim altıncı sınıf Türkçe dersi öğretim programı okuma alanının öğretmen görüşlerine göre değerlendirilmesi. (Yayımlanmamış yüksek lisans tezi). Çukurova Üniversitesi Sosyal Bilimler Enstitüsü illköğretim Ana Bilim Dalı, Adana.

Kardaş, N . (2020). Drama etkinliklerinin 7. sınıf öğrencilerinin Türkçe konuşma becerilerine etkisi. Kuram ve Uygulamada Sosyal Bilimler Dergisi, 4 (2) , 41-59 . DOI: 10.48066/kusob.828580.

Kayhan, E., Altun, S. ve Gürol, M. (2019). Sekizinci sınıf Türkçe öğretim programı (2018)'nın 21. yüzyıl becerileri açısından değerlendirilmesi. Adnan Menderes Üniversitesi Eğitim Fakültesi Eğitim Bilimleri Dergisi, 10 (2), 20-35.

Kırkpınar Nural, E. (2019). Jules Verne'in eserlerindeki tema ve iletilerin Türkçe öğretim programı bağlamında incelenmesi ve değerlendirilmesi. (Yayımlanmamış yüksek lisans tezi). Muğla Sıtkı Koçman Üniversitesi Eğitim Bilimleri Enstitüsü Türkçe Eğitimi Anabilim Dalı, Muğla.

Klenowski, V. (2010). Curriculum evaluation: approaches and methodologies. In Peterson, Penelope, Baker, Eva, \& McGaw, Barry (Eds.) International Enclyclopedia of Education. Elsevier, Oxford, 335-341.

Korucu, S. (2016). Altıncı sınıf Türkçe dersi duygular temasının klasik Türk edebiyatı metinleriyle öğretiminin öğrenci başarı, tutum ve görüşlerine etkisi. (Yayımlanmamış doktora tezi). Atatürk Üniversitesi Eğitim Bilimleri Enstitüsü Türkçe Eğitimi Ana Bilim Dalı, Erzurum.

Kurudayıoğlu, M. ve Soysal, T. (2019). 2018 Türkçe dersi öğretim programı kazanımlarının 21. yüzyıl becerileri açısından incelenmesi. Ahi Evran Üniversitesi Sosyal Bilimler Enstitüsü Dergisi, 5(2), 483-496 
Kurt, E. (2018). Altıncı sınıf Türkçe dersi kavram öğretiminde animasyon ve hikâye kullanımının başarıya etkisi (Yayımlanmamış doktora tezi). Karadeniz Teknik Üniversitesi Eğitim Bilimleri Enstitüsü, Trabzon.

Linacre, J.M. (2014). A user's guide to FACETS Rasch-model computer programs. Erişim Adresi: http://www.winsteps.com/a/facets-manual.pdf.

MEB (2015). Millî Eğitim Bakanlığı Türkçe dersi (1-8. sınıflar) öğretim programı. Ankara: MEB Yayınları MEB (2019). Millî Eğitim Bakanlığı Türkçe dersi (1-8. Sınıflar) öğretim programı. Ankara: MEB Yayınları

Mert Duran, C. N. (2016). Altıncı sınıf Türkçe dersi mevsimler alt temasında eski Türk edebiyatı metinleri kullanımının öğrencinin başarı, tutum, kalıcılık ve görüşüne etkisi. (Yayımlanmamış yüksek lisans tezi). Atatürk Üniversitesi Eğitim Bilimleri Enstitüsü Türkçe Eğitimi Ana Bilim Dalı, Erzurum.

Mutlu, H. H. ve Yurt, E. E. (2019). 6. sınıf Türkçe ders kitabındaki etkinliklerin öğrenme alanlarına dağılımının incelenmesi. Ordu Üniversitesi Sosyal Bilimler Araştırmaları Dergisi, 9 (3), 469-474.

OECD (2011). Organization for economic cooperation and development. lessons from pisa for the united states, strong performers and successful reformers in education. Paris: OECD.

Özenç, E.G. (2018). 2015 ile 2017 ilkokul Türkçe öğretim programının karşılaştırımalı olarak değerlendirilmesi. Uşak Üniversitesi Eğitim Araştırmaları Dergisi, 4(2), 38-50.

Phillips, D. C. (1995). The good, the bad, and the ugly: The many faces of constructivism. Educational Researcher; 24(7), 5-12

Sandıkçı, C. (2006). Öğretmenlerin ilköğretim altı, yedi ve sekizinci sınıf Türkçe dersi öğretimi uygulamalarıyla ilgili görüşleri: Konya ilinde bir inceleme. (Yayımlanmamış yüksek lisans tezi). Selçuk Üniversitesi Sosyal Bilimler Enstitüsü Türkçe Eğitimi Ana Bilim Dalı, Konya.

Spigner Littles, D. ve Anderson, C. E. (1999). Constructivism: A paradigm for older learners. educational gerontology, 25 (3), 203-209.

Süğümlü, Ü., Mutlu, H. H. ve Cinpolat, E. (2019). Relationship between writing motivation levels and writing skills among secondary school students. International Electronic Journal of Elementary Education, 11(5), 487-492.

Şahin, F. (2019). Altıncı sınıf Türkçe dersi ses olayları konusunda geliştirilen eğitsel oyunun akademik başarıya etkisi. (Yayımlanmamış yüksek lisans tezi). Balıkesir Üniversitesi Fen Bilimleri Enstitüsü Bilgisayar ve Öğretim Teknolojileri Eğitimi Anabilim Dalı, Balıkesir.

Şahin, D., ve Bayramoğlu, C. D. (2016). 2015 Türkçe öğretim programının metin tür ve tema seçimi bakımından değerlendirilmesi. International periodical for the languages, literature and history of Turkish or Turkic,11 (3), p. 2095-2130.

Şencan, H. (2005). Sosyal davranışsal ölçümlerde güvenirlik ve geçerlik. Ankara: Seçkin Yayıncılık.

TÜiK (2013). Türkiye İstatistik Kurumu. https://www.tuik.gov.tr/.

Veneziano L. ve Hooper J. (1997). A method for quantifying content validity of health-related questionnaires. American Journal of Health Behavior, 21(1), 67-70.

Yurdugül, H. ve Aşkar, P. (2008). Öğrencilerin teknolojiye yönelik tutum ölçeği faktör yapılarının incelenmesi: Türkiye örneği. İlköğretim Online, 7(2), 288-309.

\section{Extended Abstract}

\section{Introduction}

Individuals' knowledge acquisition process starts in the family. The gradual and regular transfer of knowledge occurs through education (Büyükarslan, 2011). Knowledge is regularly transferred to students through the content of the curricula by teachers during this process. The transfer of knowledge in schools is carried out by means of language. The more clearly language is used, the clearer and more understandable the transmitted messages will be. Korucu (2016) notes that building language awareness in individuals paves the way for developing strong language skills. The best environment to acquire the ability to use language consciously is the Turkish courses in elementary schools.

An in-depth examination and evaluation of the curricula would give information regarding their quality, widespread effects, and their contributions as well as their functionality to stakeholders. 
Besides, it is of great importance to examine the curricula in today's world where time and space converge and where the needs of the society and the individual change rapidly. The evaluation includes the descriptions of the learning objectives, outcomes, tools, and experiences (Klenowski, 2010).

Different dimensions of the $6^{\text {th }}$ grade Turkish curriculum were examined by various researchers. Some of those studies analyzed the learning areas of the curriculum (Mutlu \& Yurt, 2019) and various themes (Korucu, 2016; Kurt, 2018). Some studies were conducted to determine the effectiveness of educational games in the curriculum (Şahin, 2019). There are also studies examining different skills in the $6^{\text {th }}$ grade Turkish curriculum (Direkçi, Şimşek \& Uygun, 2020; Kurudayıoğlu \& Soysal, 2019; Özenç, 2018). Several studies were carried out to evaluate the $6^{\text {th }}$ grade Turkish curriculum (Altunkeser \& Coşkun, 2016; Aslan \& Atik, 2018; Özenç, 2018). It seems that the studies evaluating the $6^{\text {th }}$ grade Turkish curriculum are generally carried out together with those that evaluated the $7^{\text {th }}$ and $8^{\text {th }}$ grade Turkish curricula (Belet Boyacı \& Güner Özer, 2019; Kahtalı \& Çelik, 2020; Kardaş, 2016, Sügümlü, Mutlu and Cinpolat, 2019). It is noteworthy that the number of studies examining the $6^{\text {th }}$ grade Turkish curriculum in detail is limited. Thus, an in-depth examination and evaluation of the curriculum would give information regarding its quality, widespread effects, functionality, and contributions to stakeholders.

Evaluating the effectiveness of learning in the curriculum is possible through examining and evaluating it in specific time periods by taking scientific processes into consideration (Girgin, 2011). Thus, it is hoped that the evaluation of the curriculum is expected to make a contribution to the field.

\section{Method}

This study used a cross-sectional single survey model. The working group consisted of 35 faculty members working in the Turkish education departments in various universities located in 12 different locations in Turkey during the 2020-2021 academic year. Three basic criteria were considered while selecting the participants which were teaching at least one course based on the Turkish course curricula in the last five years, publishing at least one scholarly article in the field related to Turkish curricula and being a faculty member in the Turkish education department in a level 1 education faculty (Turkey Statistics Institute [TurkStat], 2013) located in any of the 12 separate zones.

The criteria included in the 2019 Turkish course curricula $6^{\text {th }}$ grade learning outcomes evaluation form were determined by taking into consideration the relevant literature review by the faculty members that formed the juries, the goals of the curriculum, its content, teaching and learning processes and dimensions of measurement and evaluation.

The data were obtained from 30 faculty members according to the 16 identified criteria. The exploratory factor analysis of the criteria was carried out through the use of SPSS program. The evaluation of the program was carried out through a multi-faceted Rasch analysis program (Linacre, 2014).

\section{Result and Discussion}

One of the significant elements of the study was the evaluation of the identified criteria in terms of convenience and difficulty in order to assess the curriculum. The findings revealed that the criteria that faculty members experienced the most difficulty in evaluating the $6^{\text {th }}$ grade Turkish course curriculum were [M1], [M2] and [M7]. Another substantial finding of the study was that the raters rated the criteria [M6] and [M11] as easy. In terms of severity and leniency in scoring, the rater $J_{16}$ displayed severity in evaluating the curriculum. On the other, the rater $J_{20}$ displayed leniency while evaluating the curriculum. 